\title{
ANALYSIS OF THE CUSTOMER SATISFACTION OF BLACK MARKET'S CHINESE SMARTPHONE
}

\author{
Liana Mangifera ${ }^{1}$, Febrianur Ibnu Fitroh Sukono Putra ${ }^{{ }^{*}}$ \\ ${ }^{1}$ Universitas Muhammadiyah Surakarta, Indonesia \\ ${ }^{2}$ Universitas Dian Nuswantoro, Indonesia \\ e-mails: ${ }^{1}$ lm122@ums.ac.id; ${ }^{2}$ fbr10@dsn.dinus.ac.id
}

Received June 6, 2021; accepted July 22, 2021; published July 28, 2021.

\begin{abstract}
Objective: This research aims to analyse the factors that influence customer satisfaction of black market's Chinese smartphone. Research Design \& Methods: The research uses quantitative approach to analyse the sample of 250 buyers of black market's Chinese smartphone across Solo Raya. The sampling technique is purposive sampling through questionnaires with a Likert scale. The analytical technique is multiple regression. Findings: The findings showed that 1) black market has a significant direct effect on customer satisfaction, 2) price has a significant direct effect on customer satisfaction, 3) product quality has a significant direct effect on customer satisfaction. Implications \& Recommendations: This research has practical implications for the marketing policies implemented by Chinese smartphone companies to increase customer awareness and product distribution policies to support increased sales at official stores and fight illegal trade in Chinese smartphone products. The social impact of the research is to contribute to changes in people's behavior in buying Chinese smartphones where there needs to be aware that the black market is an illegal store to buy products if people want to buy Chinese smartphones, then the right thing is at official stores or outlets that are already working-same with the company. Contribution \& Value Added: This research provides added value to evaluating distribution policies implemented by Chinese smartphone companies, which are considered less able to compete with the black market. So to increase market share at official stores, Chinese smartphone companies must be more severe in managing the distribution of product sales so that industrial competition can run properly.
\end{abstract}

Keywords: black market; Chinese smartphone; customer satisfaction; marketing strategy.

JEL codes: M11, M15, M31

Article type: research paper

\section{INTRODUCTION}

The current era of modernization causes information technology to become a basic need for everyone. The development of information technology is increasingly sophisticated and continues to evolve until now known with many innovations and complex and straightforward discoveries. One type of information technology is a cellphone or smartphone. The growth of smartphones in Indonesia is proliferating as if there is no end to this telecommunication device being one of Indonesia's very high needs (Park, 2020). In 2020 the number of active smartphone users in Indonesia is more than 150 million people. With such a large number, Indonesia will become the country with the fourth largest active smartphone users worldwide after China, India and America (Akkucuk \& Esmaeili, 2016). 
Several Chinese smartphone brands have dominated the market in Indonesia, such as Oppo, Xiaomi, Infinix, and Vivo (Amalia \& Asmara, 2017). With so many Chinese smartphone brands in the Indonesian market, it will undoubtedly create increasingly high business competition and will result in many challenges that every company must face. Each smartphone company will design its product marketing concepts and strategies to attract the attention of customers. Several marketing strategies such as promotions in brochures or pamphlets and social media are carried out to introduce and maintain each of these smartphones. The marketing strategy is carried out to achieve the company's goals in increasing sales, namely by creating the satisfaction that consumers expect for a product so that its existence is maintained in the market (Wang et al., 2018).

The research conducted by Thabit \& Raewf (2018) shows price has significant effect on customer satisfaction, but, the result from Adewale et al. (2013) shows price has no significant effect on customer satisfaction. The research conducted by Wantara \& Tambrin (2019) show product quality has significant effect on customer satisfaction, but, the result from Saleem et al. (2015) shows product quality has no significant effect on customer satisfaction. In some previous studies, there were no studies on the influence of the black market as a type of marketplace affecting customer satisfaction. The black market is an alternative to online stores in obtaining Chinese smartphones with various rules violations but can meet customer needs more effectively and efficiently without worries about the seller's license. This situation harms the balance of the Chinese smartphone market, so there is a need for solute regulations from policymakers. This research model aims to provide input to official stores to develop more effective marketing strategies to be able to provide awareness to customers that the black market is not accurate and restore customer behavior in buying Chinese smartphones only at official stores.

Consumer satisfaction for a product, in this case, is a smartphone product. It is essential to support marketing activities in the community as potential consumers. If consumers are not satisfied with the products they use, the company has failed to meet the expectations desired by consumers. With consumer satisfaction, the company will be able to find out how the opinion of its consumers after using the product. Consumer satisfaction refers to the consumer's assessment of his entire experience during purchase. Through quality service and marketing, the company can achieve customer satisfaction. Customer satisfaction is a term that describes the level of satisfaction experienced by customers when consuming products/services issued by producers. To achieve customer satisfaction, the company not only creates products but also value for customers (Putra et al., 2020). The marketing strategy is carried out to achieve the company's goals in increasing sales, namely by creating the satisfaction that consumers expect for a product so that its existence is maintained in the market. Consumer satisfaction for a product, in this case, is a smartphone product. It is essential to support marketing activities in the community as potential consumers. If consumers are not satisfied with the products they use, the company has failed to meet the expectations desired by consumers. With consumer satisfaction, the company will be able to find out how the opinion of its consumers after using the product. Consumer satisfaction refers to the consumer's assessment of his entire experience during purchase. Through quality service and marketing, the company can achieve customer satisfaction. Customer satisfaction is a term that describes the level of satisfaction experienced by customers when consuming products/services issued by producers. To achieve customer satisfaction, the company not only creates products but also value for customers (Oh \& Lee, 2020).

Now, Chinese smartphone products have also penetrated the Indonesian market with various series launched, which make Indonesian consumers choose this smartphone and make Chinese smartphones the second-largest smartphone selling company in Indonesia (Kwan Soo Shin et al., 2019).

On Table 1 above shows that Chinese smartphones occupy the second position as Indonesia's Top Smartphone 2020 with a market share total of $44.5 \%$. This result shows that Chinese smartphone companies can attract customers' attention and meet consumer expectations, increasing sales. Chinese smartphone products may have their advantages with various specifications created, and also, the prices offered are quite affordable for some people (Jeong et al., 2016). However, the presence of black market provides various series of outputs from Chinese smartphone companies makes customers feel that there are more substitute products with prices and quality that can meet satisfaction

JMER, 2021, 02(1), 27-40 
expectations. The black market aims to become a competitor to the official store of Chinese smartphone companies in the industry in meeting consumer satisfaction. The ability of traders in the black market to imitate Chinese smartphone products to become very similar to the original allows them to penetrate the market quickly, so it does not take long to have high competitiveness in the industry. This condition results from a lack of control from the company's management in managing product distribution channels to be easily rivalled by black market traders (Turgeman et al., 2020).

Table 1. Indonesia Top 5 Smartphone Companies, 2020 Q3 Unit Market Share

\begin{tabular}{ccc}
\hline NO & Brand & Market Share \\
\hline 1 & Samsung & $30 \%$ \\
2 & Iphone & $25.5 \%$ \\
3 & Oppo & $18.8 \%$ \\
4 & Vivo & $13.2 \%$ \\
5 & Xiaomi & $12.5 \%$ \\
\hline
\end{tabular}

Source: Teknokompas.com, IDC 2020.

This reason underlies the researcher to add the black market variable as one of the factors that affect customer satisfaction after buying a Chinese smartphone. The urgency of this research is to analyze the factors that influence customer satisfaction with the black market buyer scheme so that it becomes an evaluation material for smartphone companies to increase the competitiveness of their official stores.

The marketing strategy applied by black market traders by implementing price, product quality and the marketplace has been implemented by several official Chinese smartphone shops in marketing their products to the public. However, how much influence this strategy will have is uncertain because some consumers still debate the level of satisfaction based on the type of marketplace, price, and product quality between official stores and black markets. In the previous research of measuring customer satisfaction of Chinese smartphone users by Chen et al. (2016), Jeong et al. (2016), Rommy et al. (2018) the measurements have not been found through the marketplace. Therefore, this research measures customer satisfaction based on a relatively low price with competitive quality but adds the black market as a third variable in measuring customer satisfaction. Based on the description above, it is necessary to research with the title "Analysis of Chinese smartphone customer satisfaction who bought on the black market".

\section{LITERATURE REVIEW}

\section{Customer Satisfaction}

Consumer satisfaction is a person's feeling of pleasure or disappointment that arises after comparing the performance (results) of the product that is thought to the expected performance (results) of the product. If performance meets expectations, consumers are satisfied. If performance exceeds expectations, consumers are very satisfied or happy. Customer satisfaction can also be defined as a condition where customers' needs, desires, and expectations can be met through the products consumed. In general, customer satisfaction can be said as a person's feeling of pleasure or disappointment from comparing the products purchased by or not with his expectations (Frye et al., 2019). Competition in many industries is characterized by overcapacity and oversupply. This situation causes price cuts to become a strategic weapon to gain market share. The focus on customer satisfaction is an effort to retain consumers in the face of low-cost producers. Many companies find that several consumers are willing to pay higher prices for better service and quality. The process of retaining and satisfying current customers is much cheaper than constantly trying to attract or prospect new customers. The cost of retaining a customer is four to six times cheaper than finding a new customer. Based on the concept of customer lifetime value, efforts to maintain consumer loyalty to the company's goods and services over a long period can result in a much larger annuity than individual purchases (Saulina \& Syah, 2018).

Positive opinions or opinions from friends or family are much more persuasive than advertisements. Therefore, many companies do examine total satisfaction and examine the extent to which consumers

JMER, 2021, 02(1), 27-40 
are willing to recommend the company's products to others. On the other hand, negative word of mouth can damage the company's reputation and image. Dissatisfied consumers can affect the negative attitudes and judgments of colleagues or family towards the company's goods and services. Negative word of mouth usually spreads much faster than positive word of mouth (Vinerean, 2017).

Moreover, there is a tendency that a dissatisfied consumer is more likely to share his bad experience with others than a satisfied customer to share a positive experience. Consumers who are satisfied and loyal to a company tend to bargain less often for each purchase. In many cases, customer satisfaction shifts the focus to service price and quality. In essence, customer satisfaction is a long-term strategy because it takes a long time before it can build and get a reputation for excellent service and often requires a significant investment in a series of activities aimed at making current and future consumers happy (Thabit \& Raewf, 2018).

The indicators used by the company in measuring customer satisfaction include expectations, comparisons, performance, experience, and confirmation. Consumer expectations of an item or service have been formed before consumers buy the goods or services. When the buying process is carried out, consumers expect that the goods or services they receive follow their expectations, desires and beliefs. Goods or services following consumer expectations will cause consumers to feel satisfied. Consumers experience the actual performance of goods or services when used without being influenced by their expectations. When the actual performance of goods or services is successful, consumers will feel satisfied. The expectation compares the goods or services performance before buying with the perception of the actual goods or services performed. Consumers will be satisfied when their pre-purchase expectations match or exceed their perceptions of the product's actual performance. Consumer expectations are influenced by their experiences of using brands of goods or services different from others. Confirmation or confirmed occurs when expectations match the actual performance of the product.

\section{Price}

Currently, our economy is not bartering anymore, but already using money as a measure called price. So, the price is the value of an item expressed in money. Price is the amount of money (plus some goods if possible) required to obtain several combinations of goods and services. Companies must set a selling price for the first time, especially when developing a new product. Determination of the selling price can be a problem because the decision to determine the selling price is quite complex and must pay attention to various aspects that influence it. In practice, the price is determined by the seller and the buyer (Pi et al., 2019). The greater the purchasing power of consumers, the more likely it is for sellers to set a higher price level. Thus the seller has the hope of getting the maximum profit following the existing conditions. Companies can set the highest price to establish or maintain an image. Meanwhile, low prices can be used to form a particular image. In a market of highly price-sensitive consumers, then competitors will lower prices. Conditions like this that underlying the formation of the goal of price stabilization in specific industries (De Toni et al., 2017).

Customers tend to prefer expensive products when the only information they get is the price of the product. Customers' perceptions of the quality of a product are influenced by their perceptions of the brand name, store name, the warranty provided (after-sale services) and the country that produces the product. In general, customers perceive that price is the cost incurred or sacrificed to get the product. However, customers have different perceptions of the costs incurred even for the same product. Indicators on the price variable include affordability, price suitability with product quality, suitability of price with benefits, and competitiveness in the market (Išoraite, 2016).

Price affordability is indicated by consumers being able to reach the prices set by the company. Products usually have several types in one brand, and the price also differs from the cheapest to the most expensive. With the price set, many consumers buy the product. Price is often used as an indicator of quality for consumers, and people often choose the higher price between two goods because they see a difference in quality. If the price is higher than another, people tend to think that the quality is also better. Consumers decide to buy a product if the perceived benefits are greater than or equal to what has been spent to get it. If consumers feel the product's benefits are less than the

JMER, 2021, 02(1), 27-40 
money spent, consumers will think that the product is expensive, and consumers will think twice about making repeat purchases. Consumers often compare the price of a product with other products. In this case, the cheapness of a product is highly considered by consumers when buying the product.

\section{Product Quality}

Product quality is the ability of a product to perform its functions, and it includes the overall durability, reliability, accuracy, ease of operation and repair of the product, and other product attributes. This situation means that product quality is the totality of goods and services related to consumer desires, which in terms of product excellence are worthy of being sold according to customers' expectations. Consumers always evaluate the performance of a product, which can be seen from the ability of the product to create product quality with all its specifications so that it can attract consumers to make purchases of these products. So it can be said that the quality provided by a product can influence consumer purchasing decisions for the products offered (Ahmed \& Kahf, 2018). In addition, product quality is defined as a measure to assess that an item or service has a use-value as desired or in other words, an item or service is considered to have quality if it functions or has a usevalue as desired. In running a business, the products and services sold must have good quality or following the price offered. For a business company to survive in the face of competition, especially competition in terms of quality, companies need to continue to improve the quality of their products or services. Because improving product quality can make consumers feel satisfied with the products or services they buy and will influence consumers to make repeat purchases (Jannang \& Jabid, 2016).

Consumer attention on the level of product quality is currently increasing. This situation happens because consumer complaints are increasingly focused on the poor quality of a product. It means improving quality is a must in the business world. Consumers often disagree about what factors shape the quality of a product. The product's benefits play a critical role in this problem, even though it is subjectively only once (Aghamirian et al., 2015). Marketers must be able to make decisions about the quality of their products because the product must achieve a level of quality following its users' function and does not need to exceed. For a smartphone manufacturer, making a quality smartphone is certainly not an easy thing. Manufacturers may have included various characteristics in their smartphones to be different from other smartphones on the market. However, it will be useless if the customer thinks that these characteristics have no function or value at all in increasing their needs through the smartphone. Because in the end, what determines whether the product is successful in the market or not is the customer (Hoe \& Mansori, 2018).

The indicators of product quality include durability, reliability, style, design, and features. Durability measures the product's expected life under common or stressful conditions, a valuable attribute for specific products. Reliability measures the probability that the product will not malfunction or fail within a certain period. Style is the power to make a difference that is hard to imitate. On the downside, a vigorous style does not necessarily mean high performance. Design the totality of features that affect the product's appearance, taste, and function based on customer needs. Features are product characteristics designed to enhance product functions or increase consumer interest in the product.

\section{Marketplace}

Website technology is a web-based technology developed using a web programming language for an information space that is accessed using a browser. Website technology is the most effective way of delivering information and is most widely used by netizens and even social groups. The marketplace is an electronic interactive business community forum that provides a marketplace where companies can participate in B2B e-commerce and or other e-business activities. This situation is because buying and selling transactions in the marketplace involves relationships between sellers, not directly in the hands of the end-user/customer (Lee \& Kim, 2021). The marketplace has several characteristics include the internet is an intermediary medium to integrate business processes, sales, purchases, inventories, and orders. Without the internet as an intermediary medium, business processes only run manually and the costs used are more significant. The essence of offering from e-marketplaces is to bring together 
buyers and sellers according to their needs and offer efficiency in transactions. The marketplace is an E-Business model that deals with sellers and buyers (seller \& buyer) (Verry \& Winarno, 2019).

Marketplace in Indonesia is one of the media driving the national economy in order to face the era of globalization. For this reason, it is necessary to develop an orderly, fair and efficient marketplace. In general, an efficient marketplace can improve the investment climate in the company and facilitate the flow of input and output of goods (Budiantara et al., 2019). The marketplace is an internet-based online media where business activities and transactions are carried out between buyers and sellers (shown in Figure 1). Buyers can find as many suppliers as possible with the desired criteria to get according to market prices. At the same time, the seller can know the wishes of the buyers. The marketplace can be said to be the second wave of e-commerce and expand the combination of the consumer business (B2B, C2B and C2C) into B2B. The essence of offering from the marketplace is to bring together buyers and sellers according to their needs and offer efficient transactions (Victor et al., 2018).

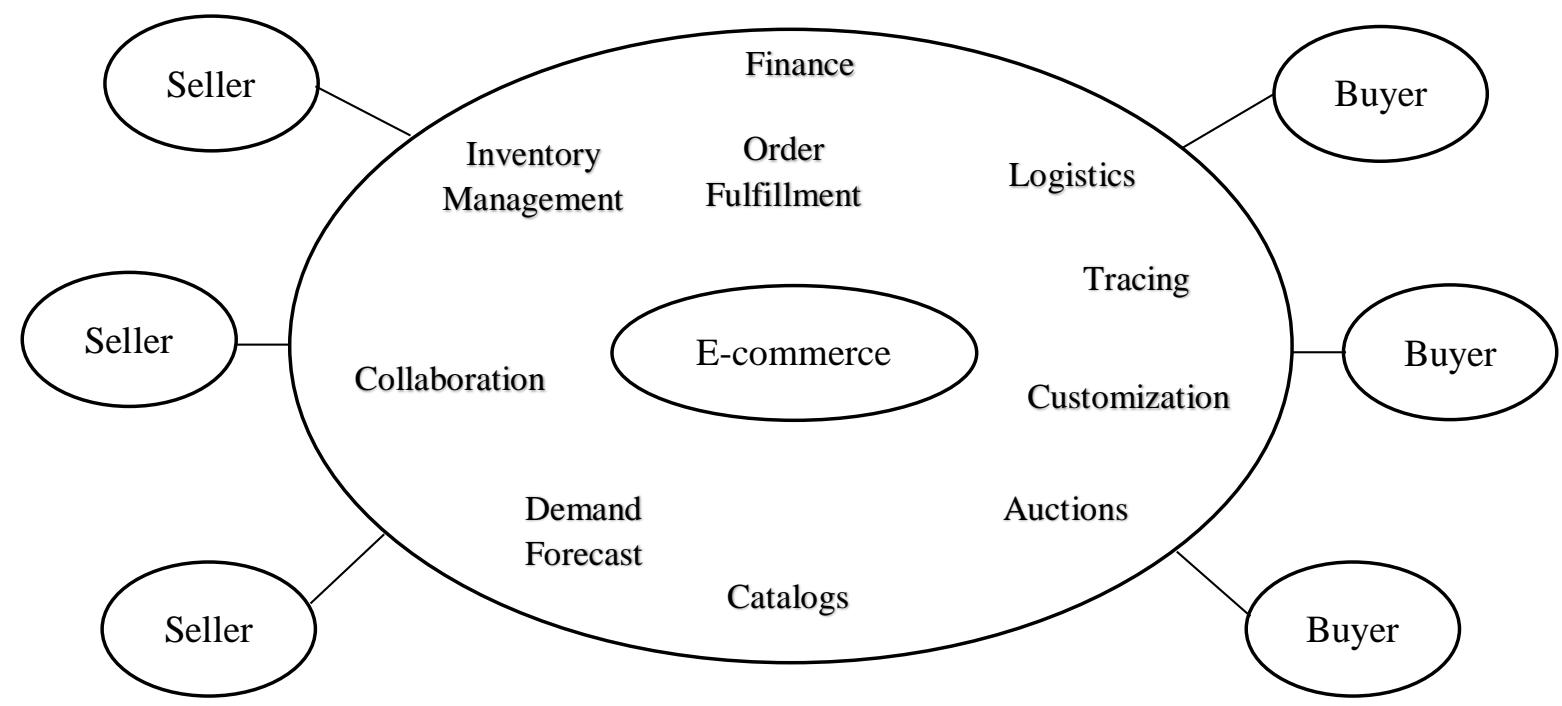

Figure 1. Marketplace Business Model

Source: Vlachopoulou et al. (2021)

There are two types of marketplaces, namely horizontal marketplaces and vertical marketplaces. Horizontal marketplaces are categorized based on the general function or product the company offers. It can be interpreted as a market used for general industries such as the sales market for smartphones, computers, clothes, and so on with lower transaction costs. At the same time, the vertical marketplace is a market used for industries that meet the particular needs of each industry, such as the sales market for concrete, steel, and the like. The foundation for the success of a marketplace is a focus, government, function, technology and cooperation. Focus on the business is undoubtedly necessary (Wirdiyanti, 2019). The company must have a strong concept and focus on the targets to be achieved. Governance in the sense of building a company requires adaptation to the regulations made by the local government. Functionality is defined as the product or service offered has the proper function and according to market needs. For technology, technology continues to develop, and companies must adapt to technology to continue to survive. Cooperation is one of the crucial factors to build a booming marketplace. By establishing good cooperation with various parties, especially the main parties of the company, it is hoped that the company's business processes will run more smoothly (Mohan \& Ali, 2019).

\section{Black Market}

In Indonesia, the black market is a sector of economic activity that involves illegal economic transactions, particularly the buying and selling of illegal goods. Transactions in the black market can be classified into two groups, namely, first, the goods sold do not meet the legal requirements of buying and selling according to sharia. Second, the goods meet the legal requirements of buying and 
selling according to the Shari'a but do not get legality from the government to avoid taxes. It is not legal to buy goods that do not meet the requirements of the Shari'a. That is, the goods sold must have a permissible benefit. For stolen goods, if the prospective buyer knows about it, it is not lawful for him to buy the goods, and he is one of those who help in sins and immorality. Goods that meet the legal requirements of buying and selling according to the Shari'a, but do not get legality from the government because they are protected from taxes, then the sale and purchase are legal (Chaudhry et al., 2019).

The prohibition of a transaction on the black market is focused on the place. It can be separated between buying and selling on the black market, so the validity of the sale and purchase contract is not disturbed by the place where the contract takes place. The sale and purchase contract on the black market for goods that meet the Shari'a's legal requirements is just not a good thing to do because it can harm the state. There has been direct supervision by the Ministry of Commerce, but still, these black market goods have escaped the supervision of the Ministry of Commerce. Yet, it all has a purpose, namely to protect and benefit consumers. If later it is found that consumers suffer losses due to the use of these black market goods in the form of material losses, it will be based on several provisions based on default and based on law (Elrod \& Fortenberry, 2018).

Black market products are sold not only to seek big profits but so that buyers can also get the desired product at a price below the market. The price offered for black market products is cheaper because they do not pay import duties. There is no quality guarantee so that goods sold on the black market that may have been reconditioned are vulnerable to damage. This increasingly widespread black market sales condition makes consumers only objects of activity for business actors who want to reap the maximum profit through black market sales practices (Chotpitayasunondh \& Douglas, 2018).

\section{Hypothesis}

\section{The Effect of Perceived Price on Customer Satisfaction}

Perceived price is also the only revenue-generating element of the marketing mix, all other elements represent only price. Perceived price is also one of the most flexible elements of the marketing mix. The perceived price level is an important factor in increasing customer satisfaction In essence, the selection of a product is influenced by knowledge, opinion and belief. These three factors are closely related to the level of experience as the fundamental basis for humans to think using logic. In their experience, humans have insight and knowledge to grade the value of a price from a product and explain a fact, which is the correct price or the right one and which one is not correct or wrong. A person or customer will choose which product performance is more effective, efficient and following his needs and according to the value of a price or cost if the performance is effective, efficient. In line with his expectations, the customer will feel satisfied and calculate the cost of procuring the product. The research conducted by Thabit \& Raewf (2018) and (Pi et al., 2019) shows price has significant effect on customer satisfaction.

\section{H1: Price has significant effect on customer satisfaction}

\section{The Effect of Product Quality on Customer Satisfaction}

Humans have many complex needs, such as basic physical needs for food, clothing, warmth and security, social needs of belonging to love, knowledge, self-expression and health need. The relationship between product quality and customer satisfaction is described by the customer's perception of the performance of the product or service, if the product is following his expectations, the customer will feel satisfied, and if it does not match his expectations, the customer will feel dissatisfied, so he will leave the product and switch to another product. Good product quality makes it easier for customer satisfaction, but if the quality of the product is poor, it is possible that customer will not satisfaction. The research conducted by Wantara \& Tambrin (2019) and (Ahmed \& Kahf, 2018) shows product quality has significant effect on customer satisfaction.

H2: Product Quality has significant effect on customer satisfaction

JMER, 2021, 02(1), 27-40 


\section{The Effect of Black Market on Customer Satisfaction}

With the black market as a substitute market in buying smartphone products, better consumer satisfaction will be created. The relationship between the black market and customer satisfaction is seen from the perspective of service, and the black market is one tool that meets customer satisfaction. One of the most significant benefits obtained by the company with the black market is customer satisfaction and competitive advantage. The quality of the information in the black market has a significant influence on customer satisfaction. The research conducted by Victor et al. (2018) and Rungsrisawat et al. (2019) shows product quality has significant effect on customer satisfaction.

H3: Black market has significant effect on customer satisfaction

\section{METHODS}

Based on the framework shown in Figure 2, the research model can be described as follows (Equation 1).

$Y=\alpha+\beta_{1} X_{1}+\beta_{2} X_{2}+\beta_{3} X_{3}+\varepsilon$ Equation 1

where, $\alpha$ is a constant, $\mathrm{Y}$ is customer satisfaction, $\mathrm{X}_{1}$ is price, $\mathrm{X}_{2}$ is product quality, $\mathrm{X}_{3}$ is black market, $\beta_{1}, \beta_{2}, \beta_{3}$ are coefficient, and $\varepsilon$ is an error.

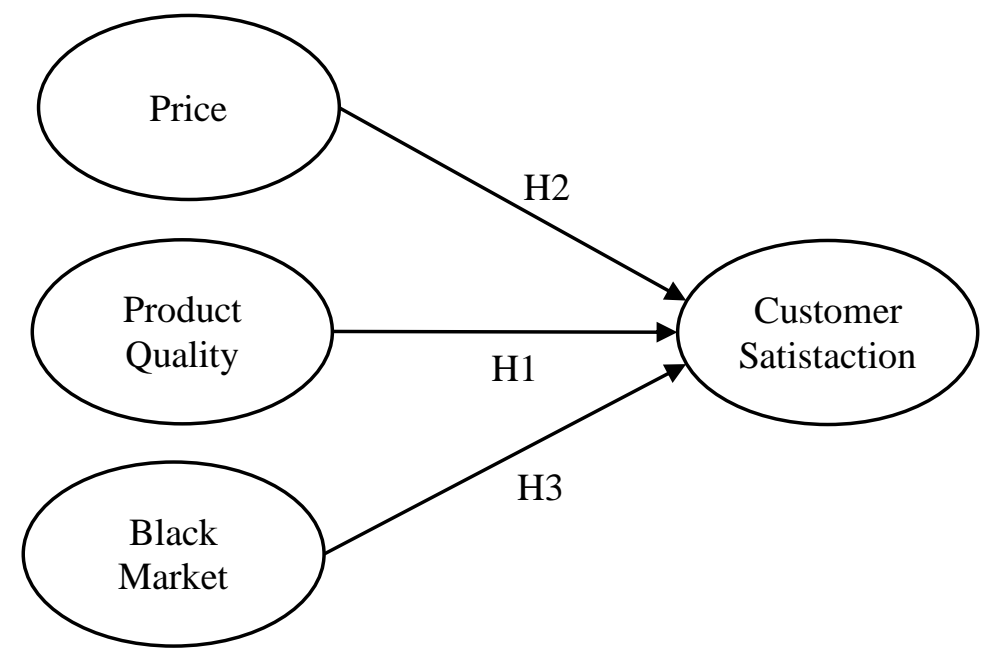

Figure 2. Research Framework

Source: The Authors

This type of research is quantitative by obtaining data through distributing personal questionnaires whose results are packaged in numbers and the analysis uses statistics so that the results are in accordance with concrete scientific principles that are empirically, objective, measurable, rational, and systematic. This research was carried out from September 2020 until March 2021. The independent variables in this research are price, product quality, and marketplace. The dependent variable in this research is customer satisfaction. The indicators used for the price variable include price affordability, price suitability with product quality, price competitiveness, price suitability with benefits. The indicators used for the product quality variable include performance, feature, reliability, conformance, durability, serviceability, aesthetics. The indicators used for the customer satisfaction variable include cognitive, affective, conative. Besides, the black market indicators used dummy data. The population in this research were all customers who had bought a Chinese smartphone. The data collection method in this research was through field surveys with distributing questionnaires personally. The method used in measuring the goodness of fit on each variable in this study uses validity and reliability tests. The validity test uses to measure the ability of the statement instrument to describe variables, while the reliability test uses to measure the consistency of respondents' answers, if the research is carried out again in the future, it will show the same good results. The data analytical technique used was the multiple regression with sampling technique was purposive sampling and get the sample total until 
250 respondents were customers who have bought Chinese smartphones in the black market. Marketing activities fulfil customer needs by creating satisfaction because customer satisfaction is a profitable long-term investment for the company's continued development. The growing trend of the role of the customer as a determinant or key holder of the company's success encourages business people to be more oriented to the interests of consumers. The research framework can be seen in Figure 2.

\section{FINDING}

An explanation of the characteristics of respondents based on the selected Chinese smartphone can be seen in Table 2.

Table 2. Respondents Identity Based on Chinese Smartphone

\begin{tabular}{cccc}
\hline No & Brand & Frequency & Percentage \\
\hline 1 & Xiaomi & 64 & $25.6 \%$ \\
2 & Vivo & 59 & $23.6 \%$ \\
3 & Oppo & 48 & $19.2 \%$ \\
4 & Realme & 37 & $14.8 \%$ \\
5 & Lenovo & 29 & $11.6 \%$ \\
6 & Infinix & 13 & $5.2 \%$ \\
\hline & & 250 & $100 \%$ \\
\hline
\end{tabular}

Source: Data processed

Based on Table 2, it can be seen that the majority of Chinese smartphone customers bought the Xiaomi with $25.6 \%$, besides customers bought the Vivo with 23.6\%, customers bought the Oppo with $19.2 \%$, customers bought the Realme with $14.8 \%$, customers bought the Lenovo with $11.6 \%$, and customers bought the Infinix brand with 5.2\%. An explanation of the characteristics of respondents based on gender can be seen in Table 3.

Table 3. Respondents Identity Based on Gender

\begin{tabular}{|c|c|c|c|}
\hline No & Gender & Frequency & Percentage \\
\hline 1 & Female & 117 & $46.8 \%$ \\
\hline 2 & Male & 133 & $53.2 \%$ \\
\hline \multicolumn{2}{|c|}{ Total } & 250 & $100 \%$ \\
\hline
\end{tabular}

Source: Data processed

Based on Table 3 it can be seen that most of the Chinese smartphone customers are male, there are 133 respondents (53.2\%), while female respondents are 117 respondents (46.8\%). An explanation of the characteristics of respondents based on income can be seen in the following Table 4 .

Table 4. Respondents Identity Based on Income

\begin{tabular}{cccc}
\hline No & Income & Frequency & Percentage \\
\hline 1 & $<$ Rp 1.5 million & 74 & $29.6 \%$ \\
2 & Rp 1.5-3.5 million & 142 & $56.8 \%$ \\
3 & $>\operatorname{Rp~3.5~million~}$ & 34 & $13.6 \%$ \\
\hline & Total & 250 & $100 \%$ \\
\hline
\end{tabular}

Source: Data processed

The highest Chinese smartphone customers in this research were 142 respondents with Rp1.5-3.5 million income, then the second largest respondents is 74 Chinese smartphone customers with $\mathrm{Rp}<1.5$ million income, and the last is 34 the Chinese smartphone customers with >Rp 3.5 million income.

Table 5. Respondents Identity Based on Education

\begin{tabular}{cccc}
\hline No & Education & Frequency & Percentage \\
\hline 1 & High school & 72 & $28.8 \%$ \\
2 & Bachelor & 127 & $50.8 \%$ \\
3 & Master & 34 & $13.6 \%$ \\
4 & Doctoral & 17 & $6.8 \%$ \\
\hline \multicolumn{5}{c}{ Total } & 250 & $100 \%$ \\
\hline
\end{tabular}

Source: Data processed 
An explanation of the characteristics of respondents based on education can be seen in the Table 5 . The highest Chinese smartphone customers in this research were 127 respondents bachelor education with $50.8 \%$, while at least the customers whom bought Chinese smartphone is 17 respondents doctoral education with $6.8 \%$. The online questionnaire distribution survey was carried out personally by contacting the respondents via e-mail and social media. The results of the validity test in this study can be seen in Table 6 below.

Table 6 . The Validity Test

\begin{tabular}{lcccc}
\hline Variable & Indicators & $\mathrm{r}_{\text {test }}$ & $\mathrm{r}_{\text {table }}$ & Decisions \\
\hline Price & P1 & 0.456 & & Valid \\
& P2 & 0.336 & 0.138 & Valid \\
& P3 & 0.733 & & Valid \\
& P4 & 0.735 & & Valid \\
Product & P5 & 0.575 & & Valid \\
Quality & PQ1 & 0.486 & & Valid \\
& PQ2 & 0.368 & 0.138 & Valid \\
& PQ3 & 0.746 & & Valid \\
Customer & PQ4 & 0.772 & & Valid \\
Satisfaction & PQ5 & 0.503 & & Valid \\
& CS2 & 0.726 & 0.138 & Valid \\
& CS3 & 0.795 & & Valid \\
& CS4 & 0.778 & & Valid \\
\hline
\end{tabular}

Source: Data processed

The validity test results show that all statement items on the questionnaire that are filled out by consumers whom bought Chinese smartphones at the black market are declared valid because each statement has a value of $r$ test $>r$ table (0.138). The statement items have been worthy of being used as a research instrument for price perception variables. The results of the reliability test in this study can be seen in Table 7 below.

Table 7. The Reliability Test

\begin{tabular}{cccc}
\hline No & Variable & Cronbach Alpha & Status \\
\hline 1 & Price & 0.758 & Reliable \\
2 & Product Quality & 0.756 & Reliable \\
3 & Black Market & 0.716 & Reliable \\
4 & Customers Satisfaction & 0.787 & Reliable \\
\hline
\end{tabular}

Source: Data processed

The reliability test results show that all variables have a Cronbach Alpha coefficient $>0.6$, so all items can be said to be reliable. Therefore, the measuring instrument used on the variables of price, product quality, and consumer satisfaction will show consistent results when used in future research. The multiple linear regression analysis which aims to analyze the effect of price, product quality, and black-market on customer satisfaction, the results are shown in Table 8 below.

Table 8. Multiple Linear Regression

\begin{tabular}{ccccc}
\hline Variables & Coefficient Beta & Beta & $\mathrm{t}_{\text {test }}$ & $\mathrm{p}$ \\
\hline Constant & 1.057 & & 2.610 & 0.006 \\
Price & 0.754 & 0.294 & 2.476 & 0.008 \\
Product Quality & 1.204 & 0.437 & 3.472 & 0.000 \\
Black Market & 0.761 & 0.329 & 2.531 & 0.007 \\
\hline$F_{\text {test }}$ & $164.529(0,000)$ & & & \\
$\mathrm{R}^{2}$ & 0.638 & & & \\
\hline
\end{tabular}

Source: Data processed

Customer Satisfaction $=1.057+0.754$ Price +1.204 Product Quality +0.761 Black Market $+\varepsilon$ 
Based on the multiple linear regression analysis results on Table 8 and Equation 2, the price has a positive and significant effect on customer satisfaction with a probability value of $0.008<0.05$, so it can be concluded that $\mathrm{H} 1$ is proven correct and supported. Product quality also shows a positive and significant effect on customer satisfaction with a probability value of $0.000<0.05$, so it can be concluded that $\mathrm{H} 2$ is proven correct and supported. The black market has a positive and significant effect on customer satisfaction with a probability value of $0.007<0.05$, so it can be concluded that $\mathrm{H} 3$ is proven correct and supported.

\section{DISCUSSION}

The test results show that price has a significant effect on consumer satisfaction (Supported). This research is in line with that conducted by Opusunju \& Ojeleye (2017), Hustić \& Gregurec (2015), and Fahrezzy \& Trenggana (2017), which state that price has a positive and significant effect on consumer satisfaction. Products with good performance have relatively lower prices than other smartphone manufacturers. The purchase price of a Chinese smartphone following the performance offered and promised by the company can create maximum consumer satisfaction. Even in the future, do not hesitate to recommend to friends or relatives to buy a smartphone. The better the consumer's perception of the price of the products offered by the company regarding the affordability of the price, the suitability of prices with the performance of smartphone products, price competitiveness compared to others will further increase the satisfaction of consumers. Consumers' assessments and perceptions of one another towards a specific price will vary depending on their characteristics and consumer background.

The test results show that product quality has a significant effect on consumer satisfaction (supported). This study is in line with that conducted by Prayidyaningrum \& Djamaludin (2016), Akkucuk \& Esmaeili (2016), and Brata et al. (2017), which states that product quality has a positive and significant effect on consumer satisfaction. A high level of product quality will result in high consumer satisfaction as well. This result is because consumers like products that offer quality, best performance, and attractive features. When buying a product, consumers will compare one product with another and pay more attention to products that benefit. This situation is because in searching for a product, consumers want to fulfil their needs and satisfy their desires. Therefore, smartphone manufacturing companies must have products with the best product quality so that consumers like the products offered by the company. Product quality is a significant advantage that companies must own because product quality in the view of consumers is something that has its scope that is different from quality in the view of producers. The higher the ability of Chinese smartphone products purchased to meet the needs and satisfy consumer desires, it will result in high consumer satisfaction as well.

The better the consumer's perception of the price of the products offered by the company regarding the affordability of the price, the suitability of prices with the performance of smartphone products, price competitiveness compared to others, the more satisfaction of consumers Consumers' assessments and perceptions of one another towards a specific price will vary depending on their characteristics and consumer background. Thus, the consumer's assessment of the price of smartphones, whether purchased at official stores or the black market, is not the same. The difference in consumer satisfaction who buys smartphones at official stores and black markets occurs. When buying smartphones at official stores, buyers don't have to wait a long time to get the product and confirm the suitability of the features, performance, product serviceability, and security of the purchased smartphone. While consumers who buy smartphones in the black market, although spoiled with easy access and transactions in buying products, require waiting time for the product to arrive first, consumers can confirm the suitability of the features, performance, product serviceability, and security of the purchased smartphone. In addition, price differences also lead to different consumer satisfaction. In the black market, smartphone prices are lower than official stores, thus fostering pride for consumers for obtaining good quality smartphones at relatively lower prices even though the security level is less guaranteed. In contrast, in official stores, it is already guaranteed product safety and quality. 
The strategic marketing policies about the distribution channel of Chinese smartphones should be implemented immediately, especially on improving information about where the customer should buy the legal smartphone product so that customers can easily understand information and sure when they want to buy it. The company must also continue to campaign for a smartphone product purchase program at official stores by further strengthening its competitiveness in the industry. In addition, there are suggestions for further research on more diverse objects, such as comparing satisfaction at official stores and black markets.

\section{CONCLUSION}

So many Chinese smartphone brands in the Indonesian market, it will undoubtedly create increasingly high business competition and will result in many challenges that every company must face. The presence of black market provides various series of outputs from Chinese smartphone companies and makes customers feel that there are more substitute products with prices and quality that can meet satisfaction expectations. So this research aims to analyze the factors that influence customer satisfaction with the black market buyer scheme so that it becomes an evaluation material for smartphone companies to increase the competitiveness of their official stores. The results of consumer satisfaction behavior in purchasing Chinese smartphones show several conclusions, including price perception has a positive and significant effect on consumer satisfaction bought Chinese smartphones in the black market, product quality has a positive and significant effect on consumer satisfaction bought Chinese smartphones in the black market, and the marketplace has an effect positive and significant impact on consumer satisfaction bought Chinese smartphones in the black market.

The research limitations in this research include the scope of research objects only in Soloraya and this research only uses surveys through questionnaires as data collection method. It aims to obtain more comprehensive results and describe the existing competitive conditions in the industry. Future research should use more variables to measure customer satisfaction and use qualitative research methods.

\section{ACKNOWLEDGEMENT}

The author would like to thank all participants involved for helping to collect, provide various data and information until this research can be completed with consistent support.

\section{REFERENCES}

Adewale, G., Adesola, \& Oyewale. (2013). Impact of Marketing Strategy on Business Performance A Study of Selected Small and Medium Enterprises ( Smes ) In. IOSR Journal of Business and Management (IOSR-JBM), 11(4), 59-66.

Aghamirian, B., Dorri, B., \& Aghamirian, B. (2015). Customer Knowledge Management Application In Gaining Organization's Competitive Advantage In Electronic Commerce. Journal of Theoretical and Applied Electronic Commerce Research, 10(1), 63-78. https://doi.org/10.4067/S0718-18762015000100006

Ahmed, O., \& Kahf, M. (2018). Customer Satisfaction Comparison between Islamic and Conventional Banks: Case Study of Qatari Banks. JKAU: Islamic Economics, 31(2), 17-32. https://doi.org/10.4197/Islec

Akkucuk, U., \& Esmaeili, J. (2016). The Impact of Brands on Consumer Buying Behavior: An Empirical Study on Smartphone Buyers. Journal of Research in Business \& Social Science, 5(4), 1-16. https://doi.org/10.20525/ijrbs.v5i4.551

Amalia, S., \& Asmara, M. O. (2017). Pengaruh Citra Merek, Harga, dan Kualitas Produk terhadap Keputusan Pembelian Handphone Merek Xiaomi di Kota Langsa. Jurnal Manajemen Dan Keuangan, 6(1), 666.

Brata, B. H., Husani, S., \& Ali, H. (2017). The Influence of Quality Products, Price, Promotion, and Location to Product Purchase Decision on Nitchi At PT. Jaya Swarasa Agung in Central. Saudi Journal of Business and Management Studies, 2(4B), 433-445. https://doi.org/10.21276/sjbms

Budiantara, M., Gunawan, H., \& Utami, E. S. (2019). Perceived Usefulness, Perceived Ease of Use, 
Trust in Online Store, Perceived Risk Sebagai Pemicu Niat Beli Online Pada Produk Umkm "Made in Indonesia" Melalui Penggunaan E-Commerce Marketplace. Jurnal Riset Akuntansi Mercu Buana, 5(1), 19. https://doi.org/10.26486/jramb.v5i1.783

Chaudhry, A. F., Hanif, M. M., Hassan, S., \& Chani, M. I. (2019). Efficiency of The Black Foreign Exchange Market. International Journal of Economics and Finance, 11(2), 165. https://doi.org/10.5539/ijef.v11n2p165

Chen, L., Yan, Z., Tang, W., Yang, F., Xie, X., \& He, J. (2016). Mobile Phone Addition Levels and Negative Emotions among Chinese Young Adults: The Mediating Role of Interpersonal Problems. Computers in Human Behavior, 55, 856-866. https://doi.org/10.1016/j.chb.2015.10.030

Chotpitayasunondh, V., \& Douglas, K. M. (2018). Measuring Phone Snubbing Behavior: Development and Validation of the Generic Scale of Phubbing (GSP) and the Generic Scale of Being Phubbed (GSBP). Computers in Human Behavior, 88, 5-17. https://doi.org/10.1016/j.chb.2018.06.020

De Toni, D., Milan, G. S., Saciloto, E. B., \& Larentis, F. (2017). Pricing Strategies and Levels and Their Impact on Corporate Profitability. Revista de Administração, 52(2), 120-133. https://doi.org/10.1016/j.rausp.2016.12.004

Elrod, J. K., \& Fortenberry, J. L. (2018). Driving Brand Equity in Health Services Organizations: The Need for an Expanded View of Branding. BMC Health Services Research, 18(Suppl 3). https://doi.org/10.1186/s12913-018-3679-4

Fahrezzy, R. S., \& Trenggana, A. F. M. (2017). Pengaruh Kualitas Produk dan Harga terhadap Keputusan Pembelian Konsumen Laptop Asus. Jurnal Indonesia Membangun, 2(2), 142-150.

Frye, W. D., Kang, S., Huh, C., \& Lee, M. J. (MJ). (2019). What Factors Influence Generation Y's Employee Retention in the Hospitality Industry?: An Internal Marketing Approach. International Journal of Hospitality Management, July, 102352. https://doi.org/10.1016/j.ijhm.2019.102352

Hoe, L. C., \& Mansori, S. (2018). The Effects of Product Quality on Customer Satisfaction and Loyalty: Evidence from Malaysian Engineering Industry. International Journal of Industrial Marketing, 3(1), 20. https://doi.org/10.5296/ijim.v3i1.13959

Hustić, I., \& Gregurec, I. (2015). The Influence of Price on Customer's Purchase Decision. Central European Conference on Information and Intelligent Systems, 1-6.

Išoraitè, M. (2016). Marketing Mix Theoretical Aspects. International Journal of ResearchGranthaalayah, 4(6), 25-37. https://doi.org/10.5281/zenodo.56533

Jannang, A. R., \& Jabid, W. (2016). Effect of Servqual and Accessibility on Customer Loyalty Through Customer Satisfaction (Study at Ternate Jati Land Mall). Australian Journal of Basic and Applied Sciences, 10(16), 275-281.

Jeong, S. H., Kim, H. J., Yum, J. Y., \& Hwang, Y. (2016). What Type of Content are Smartphone Users Addicted To?: SNS vs Games. Computers in Human Behavior, 54, 10-17. https://doi.org/10.1016/j.chb.2015.07.035

Kwan Soo Shin, S., Amenuvor, F. E., Basilisco, R., \& Owusu-Antwi, K. (2019). Brand Trust and Brand Loyalty: A Moderation and Mediation Perspective. Current Journal of Applied Science and Technology, 38(4), 1-17. https://doi.org/10.9734/cjast/2019/v38i430376

Lee, J., \& Kim, K. (2021). Impact of Social Consumption Crisis Strategy on Distribution Marketplaces' Relationships. Journal of Distribution Science, 19(3), 61-70. https://doi.org/10.15722/jds.19.3.202103.61

Mohan, V., \& Ali, S. (2019). Challenges Faced By Indian MSMEs in Adoption of Internet Marketing and E-Commerce. Academy of Marketing Studies Journal, 23(1), 1-9.

Oh, W., \& Lee, W. (2020). A Study on The Opt-in Marketing. Journal of Industrial Disribution \& Business, 11(2), 49-59.

Opusunju, M. I., \& Ojeleye, Y. C. (2017). Current Price and It Effects on Consumer Purchase Decision in Ikot Ekpene Main Market, Akwa Ibom State. International Journal of Economics and Socio-Legal Sciences, 2(6), 1-13.

Park, H. Y. (2020). A Study On The Customer Attitudes Toward The Airport IT Service: Focusing On Handling Process And Acceptance Intention. Journal of Distribution Science, 18(1), 27-34. https://doi.org/10.15722/JDS.18.1.202001.27 
Pi, Z., Fang, W., \& Zhang, B. (2019). Service and Pricing Strategies with Competition and Cooperation in a Dual-channel Supply Chain with Demand Disruption. Computers and Industrial Engineering, 138(October), 106130. https://doi.org/10.1016/j.cie.2019.106130

Prayidyaningrum, S., \& Djamaludin, M. D. (2016). Theory of Planned Behavior to Analyze the Intention to Use The Electronic Money. Journal of Consumer Sciences, 1(2), 1-12. https://doi.org/10.29244/jcs.1.2.1-12

Putra, F. I. F. S., Budiantoro, R. A., Luxfiati, B. A., \& Widawati, M. W. (2020). Consumer Satisfaction Behavior Bought Chinese Smartphone In The Official Store And Black Market In Soloraya. Jurnal Aplikasi Manajemen, 18(3), 588-596. https://doi.org/http://dx.doi. org/10.21776/ub.jam.2020. 018.03.19

Rommy, A. S. N., Moh, N. B. H. H., \& Nur, A. R. Y. N. (2018). Effect Of Brand Image And Price Perception On Purchase Decision. Journal of Business and Management, 20(8), 76-81. https://doi.org/10.9790/487X-2008027681

Rungsrisawat, S., Sriyakul, T., \& Jermsittiparsert, K. (2019). The Era Of E-Commerce \& Online Marketing: Risks Associated With Online Shopping. International Journal of Innovation, Creativity and Change, 8(8), 201-221.

Saleem, B. A., Ghafar, A., Ibrahim, M., Yousuf, M., \& Ahmed, N. (2015). Product Perceived Quality and Purchase Intention with Consumer Satisfaction. Global Journal of Management and Business Research: E Marketing, 15(1), p21-28.

Saulina, A. R., \& Syah, T. Y. R. (2018). How Service Quality Influence of Satisfaction and Trust Towards Consumer Loyalty in Starbucks Coffee Indonesia. International Advanced Research Journal in Science, Engineering and Technology, 5(10), 11-19. https://doi.org/10.17148/iarjset.2018.5102

Thabit, T. H., \& Raewf, M. (2018). The Evaluation of Marketing Mix Elements: A Case Study. International Journal of Social Sciences \& Educational Studies, 4(4). https://doi.org/10.23918/ijsses.v4i4p100

Turgeman, L., Hefner, I., Bazon, M., Yehoshua, O., \& Weinstein, A. (2020). Studies on The Relationship Between Social Anxiety and Excessive Smartphone Use and on The Effects of Abstinence and Sensation Seeking on Excessive Smartphone Use. International Journal of Environmental Research and Public Health, 17(4). https://doi.org/10.3390/ijerph17041262

Verry, \& Winarno, W. W. (2019). Analysis of Indonesian Marketplace Based on Customer Satisfaction, Trust and Loyalty. International Journal of Engineering Research and Advanced Technology, 05(02), 01-12. https://doi.org/10.31695/ijerat.2019.3371

Victor, V., Thoppan, J. J., Nathan, R. J., \& Maria, F. F. (2018). Factors Influencing Consumer Behavior and Prospective Purchase Decisions in a Dynamic Pricing Environment-An Exploratory Factor Analysis Approach. Journal of Social Sciences, 7(9), 1-14. https://doi.org/10.3390/socsci7090153

Vinerean, S. (2017). Importance of Strategic Social Media Marketing. Expert Journal of Marketing, 5(1), 28-35. https://doi.org/10.1016/S0002-9343(96)80090-8

Vlachopoulou, M., Ziakis, C., Vergidis, K., \& Madas, M. (2021). Analyzing AgriFood-Tech eBusiness Models. Sustainability, 13(10), 1-17. https://doi.org/10.3390/su13105516

Wang, P., Lei, L., Wang, X., Nie, J., Chu, X., \& Jin, S. (2018). The Exacerbating Role of Perceived Social Support and The "Buffering" Role of Depression in The Relation Between Sensation Seeking and Adolescent Smartphone Addiction. Personality and Individual Differences, 130(59), 129-134. https://doi.org/10.1016/j.paid.2018.04.009

Wantara, P., \& Tambrin, M. (2019). The Effect of Price and Product Quality Towards Customer Satisfaction and Customer Loyalty on Madura Batik. International Tourism and Hospitality Journal (ITHJ), 2(1), 1-9.

Wirdiyanti, R. (2019). The Impact of E-commerce Adoption on MSMEs Performance and Financial Inclusion (FI) in Indonesia. The Financial Services Authority, 12, 1-19. 